\title{
Volcanism and Geochemistry in Central America: Progress and Problems
}

\author{
M. J. Carr ${ }^{1}$, M.D. Feigenson ${ }^{1}$, L. C. Patino ${ }^{2}$ and J.A. Walker ${ }^{3}$
}

${ }^{1}$ Department of Geological Sciences, Rutgers University

${ }^{2}$ Department of Geological Sciences, Michigan State University

${ }^{3}$ Department of Geology and Environmental Geosciences, Northern Illinois University

\begin{abstract}
Most Central American volcanoes occur in an impressive volcanic front that trends parallel to the strike of the subducting Cocos Plate. The volcanic front is a chain, made of right-stepping, linear segments, 100 to $300 \mathrm{Km}$ in length. Volcanoes cluster into centers, whose spacing is random but averages about $27 \mathrm{Km}$. These closely spaced, easily accessible volcanic centers allow mapping of geochemical variations along the volcanic front. Abundant back-arc volcanism in southeast Guatemala and central Honduras allow two cross-arc transects. Several element and isotope ratios (e.g. $\mathrm{Ba} / \mathrm{La}, \mathrm{U} / \mathrm{Th}, \mathrm{B} / \mathrm{La},{ }^{10} \mathrm{Be} /{ }^{9} \mathrm{Be},{ }^{87} \mathrm{Sr} /{ }^{86} \mathrm{Sr}$ ) that are thought to signal subducted marine sediments or altered MORB consistently define a chevron pattern along the arc, with its maximum in Nicaragua. $\mathrm{Ba} / \mathrm{La}$, a particularly sensitive signal, is 130 at the maximum in Nicaragua but decreases out on the limbs to 40 in Guatemala and 20 in Costa Rica, which is just above the nominal mantle value of 15 . This high amplitude regional variation, roughly symmetrical about Nicaragua, contrasts with the near constancy, or small gradient, in several plate tectonic parameters such as convergence rate, age of the subducting Cocos Plate, and thickness and type of subducted sediment. The large geochemical changes over relatively short distances make Central America an important margin for seeking the tectonic causes of geochemical variations; the regional variation has both a high amplitude and structure, including flat areas and gradients. The geochemical database continues to improve and is already adequate to compare to tectonic models with length scales of $100 \mathrm{Km}$ or longer.
\end{abstract}

\section{INTRODUCTION}

The selection of Central America as a focus area by the National Science Foundation's Margins Program should increase the amount of research carried out in Central America and lead to improved understanding of all aspects of the subduction process. The primary goal of this paper is to facilitate future research in Central America; first, by updating regional data bases and second, by surveying current ideas with emphasis on assumptions, caveats, inconsistencies, flaws, unexplained observations and important problems. There are several reviews of Central American volcanology [e.g. Stoiber and Carr, 1973; Carr et al., 1982; Carr and Stoiber, 1990] and progressively refined models attempting to explain the geochemistry of diverse magma types in the region; fourth, a summary of the regional, cross-arc, and local geochemical zoning; and finally, a summary of segmentation, including a proposed first-order geochemical segmentation of the arc.

\section{DATA}

Data are in three files located at M. J. Carr's web site: http://www-rci.rutgers.edu/ carr/index.html.

CAVolcFront.zip is Table 1. It lists physical parameters of 39 Quaternary volcanic centers that comprise the volcanic front of Central America. Figure 1 shows the tectonic setting of the volcanic front and Figure 2 names the volcanic centers. With only a few exceptions, the volcanic front centers are groups of vents, including 
merges with the huge Santa Ana volcanic complex; separating them or not is arbitrary. The same is true for the Tecapa and San Miguel centers in El Salvador. Geochemistry has not proven helpful in defining dividing lines between nearby centers because the geochemical variation within a center is commonly as great as that between adjacent centers. For example, in northern Central America there is strong cross-arc chemical zonation among vents in the same center [Halsor and Rose, 1988]. The volcanoes nearest to the trench have more mafic character and generally lower LIL element contents and higher $\mathrm{Ba} / \mathrm{La}$.

Another flaw in the assumption that it is wise to group volcanoes into centers is the presence of two small volcanoes along the volcanic front at some distance from adjacent centers. Momotombito is a small composite cone in Nicaragua that is arbitrarily grouped with Momotombo even though it is $9 \mathrm{Km}$ distant. Aramuaca is a maar located $13 \mathrm{Km}$ southeast of San Miguel in El Salvador. It's chemistry is not known because no fresh samples were found. Most of Central America is volcanic and it is problematic to decide how eroded and old a volcanic structure should be to be excluded from the list. Until there is more extensive dating, it seems best to be conservative in deciding which volcanoes to include among the Quaternary centers.

Table 1. Physical parameters of Central American volcanoes

\begin{tabular}{|c|c|c|c|c|c|c|c|}
\hline $\begin{array}{c}\text { Center } \\
\text { No. }\end{array}$ & Name & $\begin{array}{r}\text { Distance } \\
\mathrm{Km}\end{array}$ & $\begin{array}{r}\text { Back } \\
\mathrm{Km}\end{array}$ & Latitude & Longitude & $\begin{array}{r}\text { Volcano } \\
\text { Volume } \\
\mathrm{Km}^{3} \\
\end{array}$ & $\begin{array}{r}\text { Center } \\
\text { Volume } \\
\mathrm{Km}^{3} \\
\end{array}$ \\
\hline 1 & Tacaná & 22.3 & 154.1 & 15.13 & -92.11 & 20 & 20 \\
\hline 2 & Tajumulco & 46.7 & 155.9 & 15.04 & -91.90 & 45 & 45 \\
\hline \multirow[t]{5}{*}{3} & Santa María & 93.9 & 147.0 & 14.76 & -91.55 & 18 & 77 \\
\hline & Santiaguito & 93.9 & 145.0 & 14.75 & -91.57 & 2 & \\
\hline & Cerro Quemado & 94.8 & 152.5 & 14.80 & -91.52 & 5 & \\
\hline & Siete Orejas & 84.7 & 148.7 & 14.81 & -91.62 & 40 & \\
\hline & Chicabál & 82.7 & 144.1 & 14.79 & -91.66 & 12 & \\
\hline \multirow[t]{4}{*}{4} & Atitlán & 137.1 & 148.9 & 14.58 & -91.18 & 33 & 330 \\
\hline & Tolimán & 135.3 & 152.1 & 14.62 & -91.18 & 18 & \\
\hline & San Pedro & 125.5 & 151.5 & 14.66 & -91.27 & 27 & \\
\hline & Los Chocoyos & 137.6 & 148.7 & 14.58 & -91.18 & 250 & \\
\hline \multirow[t]{2}{*}{5} & Fuego & 170.1 & 154.8 & 14.48 & -90.88 & 73 & 135 \\
\hline & Acatenango & 169.2 & 156.4 & 14.50 & -90.88 & 62 & \\
\hline 6 & Agua & 183.2 & 160.1 & 14.47 & -90.75 & 68 & 68 \\
\hline 7 & Pacaya & 201.6 & 159.8 & 14.38 & -90.60 & 17 & 17 \\
\hline 8 & Tecuamburro & 231.0 & 147.0 & 14.15 & -90.42 & 39 & 39 \\
\hline 9 & Moyuta & 266.5 & 152.3 & 14.03 & -90.10 & 15 & 15 \\
\hline \multirow[t]{3}{*}{10} & Santa Ana & 319.4 & 159.2 & 13.85 & -89.63 & 220 & 351 \\
\hline & Apaneca & 304.5 & 149.6 & 13.84 & -89.80 & 125 & \\
\hline & Izalco & 321.2 & 156.1 & 13.82 & -89.63 & 2 & \\
\hline
\end{tabular}




\begin{tabular}{|c|c|c|c|c|c|c|c|}
\hline & Usulután & 449.8 & 179.4 & 13.42 & -88.47 & 15 & \\
\hline & Berlin & 440.5 & 183.6 & 13.49 & -88.53 & 60 & \\
\hline & Tigre & 441.2 & 180.8 & 13.47 & -88.53 & 20 & \\
\hline & Taburete & 442.7 & 178.1 & 13.44 & -88.53 & 8 & \\
\hline \multirow{3}{*}{15} & San Miguel & 467.8 & 191.4 & 13.43 & -88.27 & 58 & 68 \\
\hline & Chinameca & 460.4 & 193.1 & 13.48 & -88.32 & 10 & \\
\hline & *Aramuaca & 480.7 & 198.6 & 13.43 & -88.13 & $<1$ & \\
\hline 16 & Conchagua & 514.4 & 199.3 & 13.28 & -87.85 & 27 & 27 \\
\hline 17 & Conchaguita & 524.9 & 198.7 & 13.23 & -87.77 & 1 & 1 \\
\hline 18 & Meanguera & 531.8 & 198.9 & 13.20 & -87.71 & 3 & 3 \\
\hline 19 & Cosigüina & 556.9 & 185.9 & 12.98 & -87.57 & 33 & 33 \\
\hline \multirow[t]{2}{*}{20} & San Cristóbal & 624.7 & 189.4 & 12.70 & -87.00 & 65 & 110 \\
\hline & Casita & 627.7 & 191.2 & 12.70 & -86.97 & 45 & \\
\hline \multirow[t]{2}{*}{21} & Telica & 644.0 & 188.0 & 12.60 & -86.85 & 28 & 30 \\
\hline & Santa Clara & 648.8 & 186.6 & 12.57 & -86.82 & 2 & \\
\hline 22 & Rota & 655.0 & 187.0 & 12.55 & -86.75 & 12 & 12 \\
\hline \multirow[t]{3}{*}{23} & Las Pilas & 664.9 & 187.5 & 12.50 & -86.68 & 14 & 28 \\
\hline & Cerro Negro & 663.3 & 186.6 & 12.50 & -86.70 & $<1$ & \\
\hline & El Hoyo & 667.0 & 187.1 & 12.49 & -86.67 & 14 & \\
\hline \multirow[t]{2}{*}{24} & Momotombo & 683.3 & 187.7 & 12.42 & -86.53 & 18 & 18 \\
\hline & *Momotombito & 692.1 & 184.6 & 12.35 & -86.48 & $<1$ & \\
\hline \multirow[t]{2}{*}{25} & Apoyeque & 711.2 & 182.8 & 12.25 & -86.33 & 6 & 9 \\
\hline & Nejapa & 720.0 & 170.0 & 12.11 & -86.32 & 3 & \\
\hline \multirow[t]{2}{*}{26} & Masaya & 742.7 & 167.3 & 11.98 & -86.15 & 168 & 178 \\
\hline & Apoyo & 754.8 & 167.7 & 11.93 & -86.05 & 10 & \\
\hline \multirow[t]{2}{*}{27} & Mombacho & 766.4 & 162.2 & 11.83 & -85.98 & 19 & 20 \\
\hline & Granada & 762.2 & 165.7 & 11.88 & -86.00 & 1 & \\
\hline 28 & Zapatera & 784.8 & 161.2 & 11.74 & -85.84 & 5 & 5 \\
\hline 29 & Concepción & 816.9 & 153.7 & 11.53 & -85.62 & 19 & 19 \\
\hline 30 & Maderas & 834.0 & 149.4 & 11.42 & -85.50 & 22 & 22 \\
\hline \multirow[t]{2}{*}{31} & Orosí & 861.5 & 109.9 & 10.98 & -85.48 & 50 & 100 \\
\hline & Cacao & 863.0 & 110.0 & 10.96 & -85.45 & 50 & \\
\hline 32 & Rincón de la Vieja & 882.3 & 103.1 & 10.83 & -85.33 & 201 & 201 \\
\hline 33 & Miravalles & 903.9 & 105.3 & 10.75 & -85.15 & 132 & 132 \\
\hline 34 & Tenorio & 920.4 & 104.9 & 10.67 & -85.02 & 95 & 95 \\
\hline \multirow[t]{2}{*}{35} & Arenal & 958.3 & 101.5 & 10.47 & -84.73 & 13 & 15 \\
\hline & Chato & 960.0 & 100.0 & 10.45 & -84.69 & 2 & \\
\hline \multirow[t]{2}{*}{36} & Platanar & 1001.7 & 105.9 & 10.30 & -84.37 & 32 & 48 \\
\hline & Porvenir & 10038 & 1022 & 1077 & -8436 & 16 & \\
\hline
\end{tabular}


CALine2.zip is Table 2. It lists the locations and relative ages of eleven volcanoes that comprise a secondary volcanic belt, landward of the volcanic front. These volcanoes are analogous to the double chains seen in parts of the Japanese arcs and other areas. Central America has few of these volcanoes and none have historic activity. This list should be modified and improved, as the ages of these volcanoes are determi ned.

Table 2. Volcanoes of the secondary front.

\begin{tabular}{llrrr}
\hline Name & Country & Latitude & Longitude & Age \\
& & & & \\
\hline Jumatepeque & Guatemala & 14.33 & -90.27 & $\mathrm{H}$ \\
Jumay & Guatemala & 14.70 & -90.00 & $\mathrm{Q}$ \\
Suchitán & Guatemala & 14.40 & -89.78 & $\mathrm{P}$ \\
Ipala & Guatemala & 14.55 & -89.63 & $\mathrm{H}$ \\
Retana caldera & Guatemala & 14.42 & -89.83 & $\mathrm{P}$ \\
Masahuat & El Salvador & 14.20 & -89.40 & $\mathrm{P}$ \\
Guazapa & El Salvador & 13.90 & -89.11 & $\mathrm{P}$ \\
Cacaguatique & El Salvador & 13.75 & -88.20 & $\mathrm{P}$ \\
El Tigre & Honduras & 13.27 & -87.63 & $\mathrm{H}$ \\
Zacate Grande & Honduras & 13.33 & -87.63 & $\mathrm{P}$ \\
Ciguatepe & Nicaragua & 12.55 & -86.15 & $\mathrm{Q}$
\end{tabular}

Age estimates; $\mathrm{H}$ is Holocene, Q is Quaternary. $\mathrm{P}$ is Plio Quaternary

CAGeochem.zip provides geochemical data for samples from Central American volcanoes. Most of the data, including nearly all the Guatemalan data, were previously published as CENTAM [Carr and Rose, 1987]. The new file contains many new columns of data for the Salvadoran, Honduran, Nicaraguan and Costa Rican samples. To first order, all the samples from volcanoes northwest of Tecuamburro volcano in southeast Guatemala are from the work of W. I. Rose Jr. at Michigan Technological University and his colleagues. M. J. Carr and colleagues at Rutgers University collected most of the rest of the samples. Many others contributed samples (e.g. G. E. Alvarado and several students from Dartmouth College)

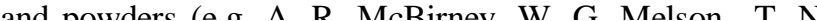

other trace element data. Quality is zero if the only data available are major elements and a few trace elements or if the trace element data are less reliable or less consistent with the rest of the database

The locations of the samples in CAGeochem are most accurately given by the easting and northing columns that refer to the map grid in $\mathrm{Km}$ units found on 1:50,000 scale topographic maps in Central America. Guatemala, Honduras and Nicaragua conveniently use the UTM grid system, but El Salvador and Costa Rica have local grids based on a Lambert projection. Other columns provide the latitude and longitude of the vent, not the sample locations. Two odd parameters are called 'Distance' and 'Back'. These units are in $\mathrm{Km}$ and refer to a Lambert conical conformal projection of the volcano locations and a subsequent $30^{\circ}$ counterclockwise rotation. The origin of this reference frame is a spot near the Middle America Trench south of the northwesternmost vol cano, Tacaná in Guatemala. Distance, measured parallel to the volcanic front, is a good estimate of distance along the arc. Back is the cross-arc direction, but it is not a good estimate of distance from the trench because the trench is not a great circle. 'Center volumes' were estimated from 1:50,000 scale maps and 100-meter contour intervals, whose areas were determined with a digitizer. The volumes of volcanic centers in Table 1 and CAGeochem are more precise than previous ones, which were made using simple geometric models. However, the accuracy is not much improved because most of the error is caused by pre-volcanic topography hidden by the volcanoes. The column entry, 'volcano volume', is incomplete because the partition of the volume of volcanic centers into their constituent volcanoes that comprise them has not been done systematically.

Silicic rocks are inadequately represented in CAGeochem for El Salvador, Nicaragua and Costa Rica because the Rutgers group has been biased toward the collection of mafic rocks. This data file should not be used to estimate unbiased average compositions. Current work in El Salvador initiated by W. I. Rose Jr. and others at Michigan Technological University, but now including several other universities, is refini ng the tephra stratigraphy and doing justice to the silicic rocks. Similarly, active research by T. A. Vogel and L. C. Patino of Michigan State University is ranidlvestahlichine the tenhra stratioranhr and 
many large silicic deposits in Nicaragua, including Cosiguiina, the Monte Galan caldera at Momotombo, Apoyeque and the Las Sierras s ection of Masaya. Williams [1983b] and Sussman [1985] describe the Mafic and silicic tephra from the youngest parts of the Masaya complex.

Panama has several Quaternary volcanic centers related to active subduction of the Nazca Plate [de Boer et al. 1991; Defant et al., 1992]. Adakites occur in young Panamanian volcanoes [e.g. Defant et al., 1991]. Small bodies of adakite lavas and dikes occur in the Talamanca range (see Figure 1) in southern Costa Rica [ Drummond et al., 1995]. These dikes and domes a re dated between 1.9 and 3.5 Ma [Abratis and Wörner, 2001] and occur above the subducting Cocos Ridge. In contrast, adakites appear to be absent along the Central American volcanic front. Panamanian volcanism is separated from the Central American volcanic front by plate boundaries cutting both the upper plate and the subducting plate. There is also a volcanic gap of about $175 \mathrm{Km}$, located above the subducting Cocos Ridge. Young and hot lithosphere of the Nazca Plate is subducting beneath Panama. The pro found tectonic and magmatic differences between Panama and Central America make it appropriate to separate these volcanic belts if one seeks to explain variations within a single convergent plate margin. However, Harry and Green [1999] group the volcanic belts of Central America and Panama and relate the large geochemical contrasts between Central America and Panama to age variations among the subducting lithosphere segments.

\section{COCOS PLATE SLAB SIGNALS}

One of the fascinating characteristics of Central Am erica is the pronounced regional variation in the geochemical ratios that define slab signals. A slab signal is a trace element or isotopic ratios that is enriched (e.g. Ba/La) or depleted (e.g. $\mathrm{Nb} / \mathrm{La}$ ) in arc magma, relative to the mantle, because of additions of hydrous fluids or silicic melts derived from a subducted slab. The wide range in ages and geologic histories of subducted slabs prevent a uniform global slab signal. Similarities in the subduction process and the relatively uniform composition o $f$ the basalt section of oceanic lithosphere allow many common features among arcs but the sediment input to subduction is variable and the resulting slah sional varies alnno with the sediment different resolution and focus on different parts of the Cocos stratigraphy.

The oceanic crust and sediments input into the subduction system appear to have low variation along strike of the trench. From Guatemala to northwestern Costa Rica the age, source and stratigraphy of the Cocos Plate crustal section are similar, suggesting a near uniform input [Aubouin et al., 1982; Kimura et al., 1997]. The tectonic processes along the Cocos-Caribbean convergent margin result in the subduction of most of the Cocos sediment section, which is clearly imaged tens of kilometers landward of the trench [von Huene et al., 2000]. Deeper processes that cannot be resolved with seismic images may remove some sediment but, to first order, the sediment section from DSDP 495, analyzed by Patino et al., [2000], characterizes what is subducted into the arc to melt generation depths.

The crustal section of the Cocos Plate consists of three stratigraphic units, a basal MORB/altered MORB, a middle carbonate unit and an upper hemipelagic unit. The MORB section has not been directly characterized and so, in Fig ure 3 the NMORB and EMORB of Sun and McDonough [1989] (diamonds) represent the MORB section. The carbonate sediments are filled triangles and the hemipelagic sediments are open triangles. Figure 3 shows several trace element ratios that track different $\mathrm{p}$ arts of the stratigraphy. These ratios are plotted on a log scale because of their wide variation in the Cocos Plate section.

$\mathrm{Ba} / \mathrm{La}$ has little variation in the sediment section but the sediments have much higher $\mathrm{Ba} / \mathrm{La}$ compared to MORB This distribution makes $\mathrm{Ba} / \mathrm{La}$ the best tracer of slab signal for the sediment section as a whole.

$\mathrm{U} / \mathrm{Th}$ variation is large, especially in the carbonate sediments, which have low contents of both $\mathrm{U}$ and $\mathrm{Th}$. The base of the hemipelagic section has values slightly higher than MORB and there is a progressive increase up section to a value of nearly 2.0. The mean values of U/Th for the two sediments are statistically indistinguishable and so, $\mathrm{U} / \mathrm{Th}$ is a tracer for the entire sediment section. However, the much higher dispersion of this ratio indicates that U/Th might provide a less clearly resolved view of regional variation along the arc than $\mathrm{Ba} / \mathrm{La}$.

$\mathrm{Ba} / \mathrm{Th}$ is exceptionally enriched in the carbonate section 
Because ${ }^{10} \mathrm{Be}$ decays with a half-life of about $1.5 \mathrm{Ma}$, it is concentrated in the upper part of the hemipelagic sedimen ts and is essentially zero below $150 \mathrm{M}$ in the Cocos Plate section [Reagan et al., 1994]. The ${ }^{10} \mathrm{Be} /{ }^{9} \mathrm{Be}$ ratio therefore provides a unique fingerprint of the top of the section.

The slab signals found in Central American magmas provide different information. The ${ }^{10} \mathrm{Be} /{ }^{9} \mathrm{Be}$ data provide the most precise depth control because ${ }^{10} \mathrm{Be}$ is present only at the top of the sediment section. $\mathrm{Ba} / \mathrm{La}$ and $\mathrm{U} / \mathrm{Th}$ represent the entire sediment section but $\mathrm{Ba} / \mathrm{La}$ has the least dispersion, suggesting it is the better of the two who le sediment signals. $\mathrm{Ba} / \mathrm{Th}$ and $\mathrm{U} / \mathrm{La}$ trace the carbonate and hemipelagic sediments, respectively.

\section{FRAMEWORK}

Central American volcanoes can be subdivided on the basis of location or tectonics, geochemistry and activity. The active system, the volcanic front, is further subdivided into segments defined both by location and by size of volcanic centers. The segmentation of the volcanic front is discussed below in section 6 . This section focuses on three volcanic systems that can be geographically or tec tonically separated: the volcanic front, the second line and behind the front volcanism (BVF) (see Figure 1). Each volcanic system has a typical geochemistry or magma type but there is some intermingling of magma types as magmas take opportunistic paths to the surface. Adding to the geochemical complexity is the existence of regional variation in both the volcanic front and BVF systems. This zoning is discussed in section 5 .

\subsection{Volcanic front}

The volcanic front is the source of all the historic volcanic activity in Central America and most of the Quaternary volcanic rocks. Several narrow lines of active volcanic centers (Figures 1 and 2) define the volcanic front. These volcanic lines or segments are 165 to $190 \mathrm{Km}$ landward of the axis of the Middle A merica Trench but the depth to the seismic zone beneath them is much more variable. The dip of the seismic zone appears to steepen toward the center of the volcanic front and so depths to the seismic zone range from less than $100 \mathrm{Km}$ in Guatemala and central Costa Rica to about $200 \mathrm{Km}$ in eastern clusters of small composite cones, shields, domes and cinder cones aligned in a grid -like pattern [ van Wyk de Vries, 1993].

Throughout Central America, with the possible exception of central Costa Rica, the volcanic front coincides with a shallow seismic zone created by right -lateral, strike-slip faulting parallel to the volcanic lines and associated $\mathrm{N}-\mathrm{S}$ normal faults and grabens [Carr and Stoiber, 1977; White and Harlow, 1993]. In this transtensional setting many volcanoes are associated with the $\mathrm{N}-\mathrm{S}$ extensional structures.

The volcanic front has many calderas that erupt silicic tephra. The geology and geochemistry of the calderas in Guatemala and El Salvador are well investigated [ e.g. Rose et al., 1999]. Most of these calderas occur on the landward side of the volcanic centers. Rose et al. [1999] established a regional tephra stratigraphic framework for northern Central America based on the voluminous eruptions from the calderas. In Nicaragua, small silicic calderas occur in the following centers: Momotombo (Monte Galan caldera), Apoyeque and Masaya (Apoyo caldera). Masaya also includes the Las Sierras caldera complex that prod uced large volumes of predominantly andesitic tephra. In Costa Rica, large silicic tephra deposits occur in association with Rincón del la Vieja, Miravalles and Barva and a small silicic tephra deposit is associated with Platanar (REFS HELPP).

The individual vents within volcanic centers commonly have more than one lava field or magma batch. The lavas range from basalt to rhyolite, but few lavas have $\mathrm{MgO}$ contents greater than 6.0 weight percent. Where the crust is thinner, as in Nicaragua, mafic basalt s are abundant. In central and western Guatemala, where thick, old continental crust occurs, basaltic lavas are usually present but their abundance and their $\mathrm{MgO}$ contents are low. Throughout Central America, large and extensively zoned plagioclase and pyroxene phenocrysts are typical. Magnetite is ubiquitous and olivine is common in basalts. An important weakness in the Central American database is the lack of regional scale mineralogical studies. The only systematic regional mineralogical variation, $\mathrm{k}$ nown to the authors, is the occurrence of hornblende in basalts and basaltic andesites that have $\mathrm{Na}_{2} \mathrm{O}$ contents greater than about 3.5 weight percent. These high $\mathrm{Na}_{2} \mathrm{O}$ contents are restricted to central and western Guatemala and central 
[Roggensack et al., 1997] but not from Masaya in Nicaragua [Bosenberg and Lindsay, pers. comm.].

\subsection{Second line}

A weakly developed second line of composite volcanoes sporadically occurs parallel to and 20 to $75 \mathrm{Km}$ behind the volcanic front (filled circles in Fig ure 1). The literature of Central American volcanism largely ignores this group because it lacks historic activity and most of the volcanoes are moderately to deeply eroded. However, El Tigre volcano in Honduras is a small composite cone that is minimally eroded and has fresh lavas and tephra. This cone is no older than many cones at the volcanic front.

In contrast to the complicated volcanic centers common at the volcanic front, most of the volcanoes in the second line grew as single composite cones. Younger cinder cones of the BVF system erupted through the flanks of several of these older composite volcanoes (e.g. Ipala and Suchitán in Guatemala and Zacate Grande in Honduras). However, these late cinder cones have a distinctively different geochemistry [Walker, 1981]. Systematic study of the secondary front is just beginning [ Patino et al., 1997]. The limited data available indicate that the lavas are calc alkaline and are plagioclase and pyroxene phyric. Lavas have $\mathrm{Ba} / \mathrm{La}$ ratios intermediate betw een the volcanic front and the BVF.

\subsection{Behind the front volcanism (BVF)}

Widespread back-arc volcanism occurs in Central America (open symbols in Figure 1). This volcanic system overlaps the second line and extends to the volcanic front, but has distinctive structural, morphological, and geochemical characteristics. Walker [1981] called this behind the front volcanism because it extends from the volcanic front to more than $200 \mathrm{Km}$ behind it. Volcanism occurs with back-arc spreading in many circum-Pacific arcs and the BVF volcanism in Central America is analogous to it, but there is an important structural difference: back-arc rifts are commonly sub parallel to the volcanic arc whereas the N-S striking extensional structures in Central America trend at a high angle to the volcanic front, which strikes about N60W. The transverse
Behind the volcanic front volcanism occurs in clusters of cinder cones, small shields and lava fields in strongly extensional settings, the largest of which is the Ipala graben in southeastern Gu atemala. There are also a small number of rhyolite obsidian domes and small calderas that produce silicic tephra. Only a few of these numerous vents are shown in Figure 1. The approximate extents of the major subalkaline BVF fields are shown in Figure 2 . There has been no historic activity in the back -arc but Holocene activity is certain given the youthful morphology of many southeast Guatemalan and Salvadoran cones and lavas. In several cases, morphologically young cinder cones occur on the flanks of the second line of composite volcanoes. In El Salvador, cinder cones with typical BVF geochemistry occur on the flanks of the historically active volcanic front centers Santa Ana [Pullinger, 1998] and Boquerón [Fairbrothers et al., 1978]. Contrarily, a recent maar, erupted $12 \mathrm{Km}$ behind Boquerón, has geochemistry more like Boquerón than the BVF cones. Clearly the plumbing is opportunistic. There is a clear geographic overlap between the volcanic front and the BVF in western El Salvador. In contrast, there is a clear separation in southeastern Guatemala [ Walker et al., 2000].

Geochemically, most BVF samples have $\mathrm{Ba} / \mathrm{La}$ ratios in the range 15 (typical mantle) to 45 (moderate slab signal). Many samples are depleted in $\mathrm{Nb}$ but $\mathrm{Zr}$ and $\mathrm{Ti}$ depletions are rare. Compared with volcanic front basalts, the BVF basalts have high $\mathrm{TiO}_{2}$ contents and are good examples of high-Ti magma (see discussion in section 4.5). These geochemical characteristics indicate a low to moderate input of fluids from the subducting plate. Typical lavas are nearly aphyric with rare olivine phenocrysts, although more evolved, phyric lavas are present, especially at the larger shield volcanoes. In a few exceptional cases (Volcán Culma northeast of Jutiapa, Guatemala and some young lavas north of Estelí, Nicaragua) there are BVF lavas with very large $(>1 \mathrm{~cm})$ phenocrysts. BVF lavas from southeast Guatemala to Tegucigalpa, Honduras to central Nicaragua (Estelí) are geochemically similar, at least as far as has been sampled. Very different alkal ine lavas occur in central and northern Honduras (Yojoa and Utila in Figure 1). Lavas from these volcanoes have no apparent contribution from the subducted slab, no HFS depletion and minimal crustal contamination. They appear to be the clearest window in to the geochemistry of the local 
The lavas are very rich in incompatible elements, plot near the alkaline/subalkaline discrimination lines and have shoshonitic affinities [Malavassi, 1991; Alvarado and Carr, 1993].

\subsection{Magma genesis}

Two different melt generation processes occur in Central America, flux melting and decompression melting. Most magmas from the volcanic front and the second line are depleted in HFS elements and enriched in the slab sign als described above. Recent studies of Central America [ e.g. Patino et al., 2000] infer that these magmas form because a hydrous or silicic flux, derived from the subducted slab, enters the mantle wedge, lowers the melting point of mantle peridotite and c auses melting. In the back-arc, magmas have negligible to moderate input of elements from the subducting slab but they occur in an extensional setting. Mantle upwelling, similar to what occurs at mid ocean ridges but on a much smaller scale, appears sufficient to cause decompression melting that generates BVF magma [Walker et al., 1995].

Cameron et al. [in press] identify magmas from the volcanic front that have geochemical characteristics compatible with decompression melting. It is probable that the dichotomy of flux melting at the volcanic front and decompression melting in the back -arc is oversimplified.

\subsection{Low-Ti and high-Ti lavas on the volcanic front}

Along most of the volcanic front, there is a bimodal distribution of $\mathrm{TiO}_{2}$ in basalts and basaltic andesites. Exceptions include eastern Nicaragua, where the $\mathrm{TiO}_{2}$ distribution is unimodal, and northwestern Costa Rica, where all samples have low $\mathrm{TiO}_{2}$ contents. There is no regionally consistent $\mathrm{TiO}_{2}$ value that separates high - Ti and low-Ti lavas because the modal values of the high -Ti lavas range from 1.15 weight percent $\mathrm{TiO}_{2}$ in El Salvador to 1.5 weight percent in western Nicaragua. The low -Ti lavas are more consistent with modes between 0.7 to 0.9 weight percent. The high-Ti and low-Ti groups usually define overlapping distributions on histograms, so precise separation is impossible. Part of the overlap is the result of magma mixing because many vents erupt both high -Ti and
high-Ti lavas differ substantially along the length of the arc and therefore, they are discussed in separate, local contexts below.

In northern Central America, Halsor and Rose [1988] pointed out several examples of paired volcanoes or short, cross-arc volcanic lineaments (e.g. Santa María-Cerro Quemado, Atitlán-Tolimán, Fuego-Acatenango, and Izalco-Santa Ana). In each case, the seaward volcano is more active, more explosive and more mafic and has steeper slopes and generally lower incompatible element contents. At the Fuego and Santa Ana cent ers, the more seaward volcano also has lower $\mathrm{TiO}_{2}$ and HFS element contents. The cross-arc volcanological and geochemical gradients in the paired volcanoes can qualitatively be explained by mixing a magma derived from flux melting (high water content and s trong HFS depletion) with a BVF magma derived from decompression melting (low water content and weak HFS depletion). Quantitative tests of this mixing hypothesis have been inconclusive so far. Establishing the cause of the gradients seen in the paired volcanoes remains an important problem.

Pacaya volcano is at the southeast end of the central Guatemala segment, adjacent to Agua and Fuego volcanoes (Figure 2). The next volcanic segment to the SE, which consists of Tecuamburro and Moyuta volcanoes, is $13 \mathrm{Km}$ closer to the trench. Behind Tecuamburro is a Holocene BVF cinder cone field called Cuilapa. The westernmost cones of this field sit on the flanks of Pacaya. The basaltic lava, currently erupting at Pacaya, has a $\mathrm{TiO}_{2}$ content of about 1.15 weight percent, a level similar to that of BVF lavas in the Cuilapa field and substantially higher than is found at the adjacent volcanic front centers. Pacaya is on the volcanic front, but its current eruption has characteristics between the low - Ti volcanic front and the high-Ti back-arc. No cross-arc geochemical gradient has been described at Pacaya. However, the volcano does appear to be receiving a back -arc input from its SE flank.

The most unusual examples of high - Ti lavas occur in the generally $\mathrm{N}-\mathrm{S}$ oriented lines of rifts, explosion pits and cinder cones that cross the volcanic front in several places in Nicaragua but most notably at Nejapa and Granada. Granada is on the northwest flank of the Mombacho center (Figure 2). Ui [1972] first described the mafi c and LILpoor lavas from these alignments. Walker [1984] and 
the more incompatible light rare earth elements and allows an up-bowed REE pattern in the later melts. These same lavas had lower $\mathrm{Nd}$ isotope ratios than the adjacent low $-\mathrm{Ti}$ lavas, suggesting they came from a more enriched source. Carr et al. [1990] explained the low light REE and LIL element contents, coupled with the relatively enriched $\mathrm{Nd}$ isotopes, by proposing an initially enriched source that had recently been depleted of its incompatible elements by an episode of low degree melting. Reagan et al. [1994] prefer to derive the high - Ti lavas from the same source as the low-Ti lavas. Walker et al. [2001] explain the high variability in the NG basalts through variable contributions from the subducting slab.

In central Costa Rica, high-Ti and low-Ti lavas are present in each volcanic center. The high -Ti lavas here differ only slightly from the low-Ti lavas; they have higher $\mathrm{REE}$ and HFS contents and lower $\mathrm{Ba}, \mathrm{Sr}$ and $\mathrm{Pb}$, indicating an origin involving lower degrees of melting and a weaker slab input [Reagan and Gill, 1989].

\subsection{Non-uniform distribution of high-Ti magmas}

The presence of two or more magma types at the same volcanic center should be considered normal in Central America. Many volcanic front centers erupt all the magma types found in the region, while others do not. Field observation suggest some controls on where the magmas come from and their ascent paths. For example, the volcanoes Moyuta and Tecuamburro (Figure 2) have only low-Ti lavas and are separated from the Cuilapa high -Ti cinder cone field by a gap of about $15 \mathrm{Km}$. The immediately adjacent volcanoes, Santa Ana in El Salv ador and Pacaya in Guatemala, are overlapped by BVF cinder cone fields. Both of these centers have some lavas with high-Ti, BVF characteristics. In this region high -Ti lavas appear to migrate to the front from the back -arc in some cases but not in others. These field observations suggest separate locations for the generation of high - Ti and low-Ti magmas, followed by migrations to the same vent. The low-Ti magmas are likely generated in the mantle wedge by a slab-derived flux. The back-arc magmas occur in extensional structures forming behind the volcanic front. Extensional structures in the crust can facilitate the along strike movement of magma. Where these structures extend into the volcanic front as thev do at Pacava and Santa Ana potential to erupt either type of magma, regardless of distance from the trench. At the extreme, these field observations suggest the high-Ti and low-Ti magmas follow the same flow paths and share a common locale for the melting processes. The presence of both high - Ti and low-Ti lavas with minimal soil development at the Las Pilas and Telica centers argue that there is minimal time lag and random sequencing in the eruptions of these magma types. The apparently low level of hybridization in these young lavas is surprising if they indeed share an extensive subcrustal plumbing system.

The intimate association of high -Ti and low-Ti magmas at Nicaraguan centers could be due to tectonic factors. First, there are no large extensional structures extending north of the volcanic front, limiting decompression melting due to extension in the back -arc. Second, the Nicaraguan seismic zone progressively steepens and becomes nearly vertical below about $150 \mathrm{Km}$ (Protti et al., 1995). Steep descent of the slab may lead to steep counterflow in the mantle that rises into the arc to replace mantle drawn down by the slab. In this model, decompression melting occurs without extension in the back -arc and the sites of magma generation for the low-Ti and high-Ti magmas would be closer than they are in northern Central America but still separate.

The only relationship between the physical characteristics of the volcanoes and the variety of erupted magmas is that many large volcanic centers have a more restricted range of chemistry. The clearest exam ple of this is Masaya, a shield volcano, with a volume of about 180 $\mathrm{Km}^{3}$, which makes it the largest center in the eastern Nicaragua segment. Walker et al. [1993] explained the compositional homogeneity of Masaya's lavas by magma mixing and AFC processes in a large shallow magma chamber. San Cristobal, the largest volcanic center in western Nicaragua, is not as homogeneous as Masaya, but does have the smallest range in $\mathrm{Ba} / \mathrm{La}$ and $\mathrm{U} / \mathrm{Th}$ ratios among the centers in this segment. The tendency for large centers to be more extensively mixed argues that the best places to find the widest range of magma types are small to medium sized volcanic centers with multiple distinct vents. In Nicaragua, the widest range of magmas occurs at Telica, a moderate sized center $m$ ade from as many as six small, overlapping volcanoes [Patino et al., 2000]. 
[e.g. Carr, 1984; Plank and Langmuir, 1988; Carr et al., 1990; Leeman et al., 1994; and Patino et al., 2000]. Similarly, cross arc zoning is thoroughly described by Patino et al., [1997] and Walker et al., [2000].

\subsection{Mantle zoning}

The first order mantle zoning is the presence of unusual isotopic ratios and trace element contents in basalts from central Costa Rica and northern Panama. Geochemically, these basalts are similar to the basalts produced by the Galapagos hot spot. Although the unusual nature of central Costa Rican volcanics was apparent in their steep REE patterns and high LIL element contents, Carr et al. [1990] tried to integrate this group into the rest of the arc. Tournon [1984], Malavassi [1991], Kussmaul et al., [1994] and Leeman et al., [1994] showed that the magmas of central Costa Rica were distinct from those of the rest of Central America and had an ocean-island basalt (OIB) character. More recently, Reagan et al. [1994] showed that the distinction be tween the central Costa Rican lavas and the lavas in western Costa Rica and Nicaragua was clear in U-series isotopes and that the boundary was gradational across western Costa Rica and possibly into eastern Nicaragua. In $\mathrm{Pb}$ isotope space the Quaternary and Tertiary lavas of central Costa Rica plot in the OIB field and, like the Galapagos hot spot, extend from the MORB field toward the to the high mantle uranium (HIMU) variety of OIB [Feigenson et al., 1996].

Figure $4 \mathrm{a}$ shows ${ }^{206} \mathrm{~Pb} /{ }^{204} \mathrm{~Pb}$ values along the volcanic front. ${ }^{206} \mathrm{~Pb} /{ }^{204} \mathrm{~Pb}$ values are sharply higher in central Costa Rica, with values of 18.8 to 19.3 . Northwest of central Costa Rica, the ${ }^{206} \mathrm{~Pb} /{ }^{204} \mathrm{~Pb}$ values are less than 18.7 , indicating a source similar to EMORB-source mantle. Refining the location and nature of the boundary between the two mantle domains in Costa Rica is an important problem.

There is little agreement on the origin of the unusual magmas in central Costa Rica. Most studies agree that the mantle source has Galapagos hot spot charact eristics, but there are many ideas on how that source gets into the present volcanic system. Abratis and Wörner [2001] cite a window in the subducting Cocos Plate, inferred from plate reconstructions [Johnston and Thorkelson, 1997], that passed over it and Galapagos -like magma erupts where this mantle is currently melting.

A second aspect of mantle zoning consists of possible variations in the EMORB-like mantle that seems to be the primary source for Central American magmas [Patino et al., 2000]. Very little is known about possible variations because inputs from the slab prevent clear views of this source. One exception is the alkali basalt fie ld near Lake Yojoa, Honduras. These back-arc basalts are close to and likely related to the transform fault system that separates the Caribbean and North American plates [ Walker et al., 2000]. The isotopic and trace element characteristics of Yojoa lavas are consistent with derivation by low degree melting of a source like the EMORB -source of Sun and McDonough [1989]. Chan et al. [1999] found $\mathrm{d}^{6} \mathrm{Li}$ values in two high-Ti Nicaraguan lavas and one back-arc lava at Aguas Zarcas in Costa Rica that are higher than MORB, suggesting the mantle beneath much of Central America may have isotopically light composition, consistent with a source, less depleted than MORB.

\subsection{Crustal zoning}

The crust along the volcanic front of Central America is thicker at both ends of the arc. In central and western Guatemala the volcanoes sit on the edge of a plateau comprising Paleozoic schists through Tertiary volcanics, whereas in Costa Rica, the basement appears to be Cretaceous and younger oceanic crust, sediments and volcanics [Weyl, 1980]. The Costa Rican crust contrasts with neighboring Nicaragua. In Costa Rica, most Tertiary and Quaternary volcanics appear to be superposed, suggesting voluminous intrusive and extrusive arc magmas created the thick crust in central Costa Ri ca. In Nicaragua, the Tertiary and Cretaceous volcanic deposits are, for the most part, progressively further inland [ McBirney, 1985; Ehrenborg, 1996], resulting in a relatively thin crust beneath the Nicaraguan volcanic lines. These crustal variations have isotopic and major element consequences.

From El Salvador to western Costa Rica, the $\mathrm{Sr}$ and $\mathrm{Nd}$ isotopes of lavas define an array with an unusual positive correlation [Feigenson and Carr, 1986]. The high Nd and high $\mathrm{Sr}$ end of the array has isotopic val ues consistent with derivation from EMORB-like mantle after addition of $\mathrm{Sr}$ 
obvious here is the highly radiogenic nature of the older crust found only in this area. Crustal contamination occurs all along the arc, but outside of central and western Guatemala, the assimilant is young enough and similar enough to present magmas that contamination is a minor consideration

The most interesting zoning, related to the crust, occurs in major elements and physical parameters. Carr [1984] and Plank and Langmuir [1988] related volcano heights, maximum magma density, minimum $\mathrm{SiO}_{2}$ contents and $\mathrm{Na}_{2} \mathrm{O}$ and $\mathrm{FeO}$ contents to estimated crustal thickness (Figure 5). Carr [1984] explained the correlations between crustal thickness, volcano heights, maximum magma density and minimum $\mathrm{SiO}_{2}$ content through a model that used ponding at the base of the crust and magma compressibility to set maximum magma densities along the arc. Magma density then controlled the other parameters, except for $\mathrm{Na}_{2} \mathrm{O}$. Although thicker crust should increase fractionation and moderate pressures, coupled with high water contents, should suppress plagioclase crystallization, these two effects increa se $\mathrm{Na}_{2} \mathrm{O}$ only a modest amount. The positive correlation between $\mathrm{Na}_{2} \mathrm{O}$ and crustal thickness was not explained.

Plank and Langmuir [1988] argued that $\mathrm{Na}_{2} \mathrm{O}$ and $\mathrm{FeO}$ contents in arc lavas, both in Central America and globally, are controlled by the extent of melting and the mantle potential temperature, a model well established for mid ocean ridges. The thickness of the crust was assumed to control the extent of melting because the sharp density contrast at the base of the crust will stop rising diapirs that are undergoing decompression melting. This model easily explains the regional variations in major elements and is consistent the magma ponding model of Carr [1984]. However, this major element derived model is very different from the magma genesis model derived from trace elements and described below in section 5.4. Reconciling these different models is an important issue.

\subsection{Zoning of slab signals}

Across the arc, the intensity of slab signal, as estimated from $\mathrm{Ba} / \mathrm{La}$, U/Th, ${ }^{87} \mathrm{Sr} /{ }^{86} \mathrm{Sr}, \mathrm{B} / \mathrm{La}$ or ${ }^{10} \mathrm{Be} /{ }^{9} \mathrm{Be}$, decreases behind the front but not in a consistent manner [ Walker et al., 2000]. Cross-arc transects more than $100 \mathrm{Km}$ in length which varies in a symmetric pattern centered on western to central Nicaragua. $\mathrm{Ba} / \mathrm{La}$ and $\mathrm{U} / \mathrm{Th}$, which vary only slightly down the Cocos Plate sediment stratigraphy, most clearly show this regional variation but other ratios are also useful (see Figures 4b, 5c, 5d and 7c). Maxima occur in Nicaragua between Telica volcano, which has the maximum $\mathrm{Ba} / \mathrm{La}$, and Masaya volcano, which has the maximum ${ }^{10} \mathrm{Be} /{ }^{9} \mathrm{Be}$ and maximum ${ }^{87} \mathrm{Sr} /{ }^{86} \mathrm{Sr}$ outside of Guatemala. The intensity of the slab signal varies by at least a factor of four in $\mathrm{Ba} / \mathrm{La}$, so the signal is robust. $\mathrm{Ba} / \mathrm{La}$ and $\mathrm{U} / \mathrm{Th}$ correlate well enough $(\mathrm{r}>0.80)$ with ${ }^{10} \mathrm{Be} /{ }^{9} \mathrm{Be}$ to be proxies for it and therefore are unambiguous, easily measured indicators of subducted sediment. $\mathrm{Ba} / \mathrm{La}$ is a superior slab signal because of its lower variation in the Cocos Plate stratigraphy (see section 3).

Since 1990, the working model to e xplain the regional variation in intensity of slab signal has been based on the positive correlation between slab signal and apparent degree of melting, estimated from the overall slope of REE patterns. For magmas derived from the same source, higher $\mathrm{La} / \mathrm{Yb}$ equals steeper REE slope and implies lower degree of melting. The mirror image in the along strike variations of $\mathrm{La} / \mathrm{Yb}$ and $\mathrm{U} / \mathrm{Th}$ (Figure $5 \mathrm{c}$ and $5 \mathrm{~d}$ ) shows the regionally consistent, positive correlation between slab signal and degree of melting. The La/Y b plot has a log scale to allow for the anomalously high $\mathrm{La} / \mathrm{Yb}$ values in central Costa Rica derived from the Galapagos -like mantle in this area. Even excluding the central Costa Rican data (crosses at distances of $1000 \mathrm{Km}$ and greater in Figure 5), there is a convincing mirror image between $\mathrm{La} / \mathrm{Yb}$ and $\mathrm{U} / \mathrm{Th}$. A further constraint on models attempting to explain the regional variation in slab signal arises from a crude negative correlation between degree of melting and volumes of erupted volcanics. Nicaragua, which has the lowest $\mathrm{La} / \mathrm{Yb}$ (or highest degree of melting), also has smaller volcanoes, just the opposite of what would be expected. Although there are huge variations in volcano size over short distances, Figure 7 a shows that there has been less magma production in Nicaragua than in other segments of the arc.

[Carr et al., 1990] reconciled the positive correlation between slab signal and apparent degree of melting and the negative correlation between degree of melting and volumas of arunted volmanice ho nronnocino a renctant slah 
enriched in the lavas. Measurements of $\mathrm{H}_{2} \mathrm{O}$ and incompatible elements in Mariana Trough lavas indicate this assumption is valid [Stolper and Newman, 1994].

The regional variations in slab signal reflect an unresolved combination of changes in slab flux and changes in magma production rate. A high slab signal is not the same as a high slab flux. The ratios used as slab signals are dimensionless, whereas a flux should be in units of mass per unit time per arc length. A very high slab signal, such as a $\mathrm{Ba} / \mathrm{La}$ ratio of 100 , could be either a high flux of $\mathrm{Ba}$ into an average sized magma batch or an average flux of $\mathrm{Ba}$ into a small magma batch. The relative amounts of slab flux and magma are the same, but the fluxes and batch sizes are different. It is well established that there are strong regional variations in slab signal along the volcanic front. These may reflect changes in flux or a linkage between flux focusing and degr ee of melting, as suggested by Carr et al., [1990]. This problem will not be unraveled until there are well -determined estimates of magmatic flux along the arc, or reliable geochemical methods of relating a signal to a flux.

A local (intravolcano) variati on adds more complexity to the slab signal [Patino et al., 2000]. Separate magma batches at a volcanic center differ in the major and trace element ratios that most emphasize the contrast between the carbonate and hemipelagic sections of the subducted Cocos Plate, which are $\mathrm{Ba} / \mathrm{Th}$ and U/La (Figure 3). Lavas with apparently low hemipelagic content (high $\mathrm{Ba} / \mathrm{Th}$ and low $\mathrm{U} / \mathrm{La}$ ) also have slightly lower $\mathrm{K}_{2} \mathrm{O}$ contents, as would be expected if the $\mathrm{K}_{2} \mathrm{O}$-rich hemipelagic muds do not contribute to the flux. At well -sampled volcanoes, there are binary mixing arrays in $\mathrm{Ba} / \mathrm{Th}$ versus $\mathrm{U} / \mathrm{La}$, two of which, Telica and Arenal, are shown in Figure 6, along with all the data for the eastern Nicaragua segment. The upper left end of the Telica array (the high $\mathrm{Ba} / \mathrm{Th}$ end) can be modeled as a mixture of mantle + altered oceanic crust + carbonate. The other end of the array (the high U/La end) is reached just by adding hemipelagic component to the previous mix. The Arenal array differs from the Telica array primarily by having smaller sediment amounts. In general, the distance of a mixing array from the mantle point, EM, corresponds with the strength of the slab signal, with western Nicaragua (Telica) being the maximum. These apparent binary mixing hyperbolae occur in all cormants of the are aveant for aactarn Nicaramia In for the hemipelagic sediments (high $\mathrm{Ba} / \mathrm{Th}$ ). These two melts are then mixed, creating the array. For most of the arc, this presumably complicated process generates paral lel arrays, implying some unknown process that generates constant proportionality. Similarly, Reagan et al. [1994) discovered that slab tracers, presumed the result of fluid transport, correlated well with Th addition, even though Th should be immobile in a hydrous fluid. Delivering the correct amount of Th in a separate melt is possible only if the fluid-melt proportions are just right. These aspects of Central American geochemistry have a suspicious just right quality, which strongly suggests an importa nt process that is not understood.

The hemipelagic sediments carry the bulk of the incompatible elements in the sediment section. Removing some or all of the hemipelagic section can generate the arrays in Figure 6. If this is the sole cause of the loca variation, then the hemipelagic section is sequestered, removed or redistributed on short time and length scales. Because the oceanic crust offshore Nicaragua has a graben and horst structure, the hemipelagic section could be removed from the horsts and doubled into the grabens [ von Huene et al., 2000; Patino et al., 2000]. Alternatively, there may be a melt of hemipelagic sediments that mixes with a hydrous flux that mobilizes elements from the rest of the Cocos Plate section. The cause of the local va riation is not well understood.

5.4 Are regional variations in degree of melting controlled by slab flux, extent of melting column or both?

Two models call upon differences in degree of melting to explain regional variations across Central America. The earlier model, Plank and Langmuir [1988], relies on changes in crustal thickness to change the melting heights of diapirs feeding the volcanoes. This model has global application to arcs and is widely accepted in the mid -ocean ridge setting. The later mod el [Carr et al., 1990] attempts to explain the correlation of slab signal (e.g. U/Th in figure $5 \mathrm{~d}$ ) with degree of melting (inverse to $\mathrm{La} / \mathrm{Yb}$ in Figure 5c). In this model, an external physical control, slab dip, controls the focusing of slab flux, which, in turn, controls degree of melting. The crustal thickness model has a realistic physical basis (variation in crustal thickness) but dnes not exnlain the reoinnal variation in slah sionals like 
negative correlation. Therefore, the two models seem to be complementary, but whether by cause or by accident is not known.

\section{SEGMENTATION OF THE VOLCANIC FRONT GEOGRAPHY, VOLUME AND GEOCHEMISTRY}

The volcanic front can be segmented in two ways. The locations of the active volcanic centers define eight lineaments or volcanic segments that are separated by changes in strike and or dextral steps of as much as $40 \mathrm{Km}$. The boundaries between the segments are the stippled bars in Figure 7b. The distribution of volumes of erupted volcanics in Figure 7a defines a less obvious segmentation. The volumes of volcanic centers are lognormally distributed, but this distribution does not appear to be spatially random because there are several progressions starting from a large volcanic center and proceeding to successively smaller ones. There are seven very large volcanic centers (named in Figure 7a) that define volume segments. The boundaries between the volume segments are roughly located at the small volcanoes out o $n$ the tails of the volume progressions. These two methods of segmenting the arc do not give exactly the same results but there is considerable overlap. One difference is that the volume distribution is continuous across the two northwesternmost volcanic segments in Guatemala, apparently unaffected by the step in the volcanic front. The other two differences are minima in volumes in central El Salvador and eastern Nicaragua where there is no volcanic segmentation.

Most of the eight geographic lineaments w ere recognized by Dollfus and Montserrat [1868] but, despite their long residence in the literature, their origin is not explained. Stoiber and Carr [1973] and Carr and Stoiber [1977] pointed out numerous geological features that were discontinuous at the same places as the volcanic lineaments and suggested that segmentation of the upper plate was initiated by breaks in the lower plate. However, this was not proved and the question of whether lower plate irregularities broke the upper plate or upper plate structures imposed a structural pattern on the descending plate was not resolved. Extensive marine geologic investigations offshore Costa Rica discovered structures in the subducting Cocos Plate, such as the Quepos and Fisher Ridges (Figure boundary between oceanic crust generated by the East Pacific Rise (EPR) and oceanic crust generated by the Cocos-Nazca spreading center (CNS) (dotted line in Figure $7 b$ ) does not generate an obvious volcanic segment. Protti et al., [1995] also tentatively identified a small bend in the intermediate depth seismicity that coincides with the largest right step in the volcanic front. Overall, the geophysical data are beginning to identify the causes of the volcanic segmentation. In central Costa Rica, the subducting Cocos Plate initiates segmentation.

The average spacing between volcanic centers is $27 \mathrm{Km}$ and the distribution of spacings is Poisson with $?=24 \mathrm{Km}$. D'Bremond d'Ars et al., [1995] derived Poisson or random distributions of volcano spacings at arcs by superposing several generations of diapirs originating via Raleigh Taylor instability. The distribution and spacing of volcanic centers in Figures 1, 2 a nd 7b agrees with their model but the distribution of erupted volumes (Figure 7a) suggests that earlier generations of diapirs influence later ones. Along Central America, seven peaks in the volume distribution occur at intervals of 120 to $180 \mathrm{Km}$. The se ven distinctly larger centers in Figure 7a may have originated from an initial generation of diapirs. Atitlán, Tecapa, and Rincon de la Vieja are flanked on both sides by progressively smaller centers, suggesting an underlying physical control to the volu me distribution. The minima in the volume distributions commonly coincide with one end or the other of the geographically defined segments.

It is surprising that there is any order (Figure 7a) in the distribution of volumes of volcanic centers. Radiome tric dating is needed to determine to what extent the volume differences are caused by different ages or by different rates of eruption. Volume is the cumulative result of eruptions that are large enough and durable enough to resist vigorous tropical erosion processes. Tephra eruptions of $10 \mathrm{Km}^{3}$ size can be largely removed in a few centuries [Williams, 1983a]. Furthermore, substantial volume can be instantaneously removed by caldera-forming events. Persisting volume is added primarily by lava fields and domes, created in decades -long eruptions, such as the ongoing eruptions of Pacaya, Arenal, and Santiaguito (part of the Santa María center. In Guatemala, there are morphologically young cones and barely recognizable roots but few volcanic edifices at int ermediate stages of erosion. 
stratigraphic relationships suggest that the volumes of volcanic centers are the sum of roughly the last 100,000 years of activity minus substantial volumes of distal and eroded pyroclastic deposits and moderate volumes of lava that were eroded.

The physical segmentation shown by volcano locations has been recognized for a long time but attempts to rela te this structure to geochemical features have failed. Accumulating geochemical data (Figure 7c) now allow a provisional geochemical segmentation of the arc based on three changes in gradients of $\mathrm{Ba} / \mathrm{La}$ versus distance along the arc and three offsets that coincide with the geographically defined segment boundaries. The recent discovery of the local variation, caused by variation in the hemipelagic component of slab flux, adds an additional tool for measuring abrupt changes in regional variation.

Close examination of the Cocos Plate sediment section (section 3) shows that $\mathrm{Ba} / \mathrm{La}$ is has the most uniform distribution in the section plotting $\mathrm{Ba} / \mathrm{La}$ versus distance along the arc (Figure 7c) provides evidence for geochemical segmentation. The $\mathrm{Ba} / \mathrm{La}$ distribution al ong the arc shows two types of discontinuities; changes in the gradient of $\mathrm{Ba} / \mathrm{La}$ versus distance; and abrupt offsets. An additional factor is the local variation described above, which is best seen in U/La versus $\mathrm{Ba} / \mathrm{Th}$ space. The signal of the uppermost unit of the Cocos Plate stratigraphy (U/La) is reduced or missing in many lavas, presumably by loss or redistribution of hemipelagic muds as they are subducted. Examination of $\mathrm{U} / \mathrm{La}$ versus $\mathrm{Ba} / \mathrm{Th}$ allows qualitative description of the amount of hemipelagic component present in each segment. In the summary below, which runs from SE to NW along the arc, slab signal is synonymous with $\mathrm{Ba} / \mathrm{La}$ (Figure 7c).

Central Costa Rica (crosses in Figure 7c) has a constant, low slab signal with hemipelagic component present and variable.

Western Costa Rica (Xs) has a constant, moderate slab signal with hemipelagic component present and variable.

Eastern Nicaragua (pointed crosses) has a very strong gradient in slab signal from low in the SE to high in the NW. Masaya volcano near the NW end of this segment is the global maximum in $\mathrm{Be}$ isotope ratio. The hemipelagic component is not only present but, in contrast to other slab signal from high (SE) to low (NW). The hemipelagic component is present and variable.

Guatemala (circles) has an increase in $\mathrm{Ba} / \mathrm{La}$ at the border with El Salvador. This offset coincides with the onset of extensive back arc volcanism in southeast Guatemala. There is a strong gradient in slab signal from high (SE) to low (NW) across Guatemala. The hemipelagic component is present and variable. Central and western Guatemala have $\mathrm{Sr}$ and $\mathrm{Nd}$ isotope systematics that are perturbed by assimilation of Paleozoic crust [ Carr et al., 1990].

One possible explanation for the offsets in $\mathrm{Ba} / \mathrm{La}$ could be that the steps in the volcanic front chan ge the depth to a smoothly varying Wadati-Benioff zone and that depth to the seismic zone controls $\mathrm{Ba} / \mathrm{La}$. The cross -arc zoning in Honduras [Patino et al., 1997] does show decreasing Ba/La with increasing depth to the seismic zone. If depth to the seismic zone controls $\mathrm{Ba} / \mathrm{La}$, then large geographic steps by the volcanic front should produce large jumps in $\mathrm{Ba} / \mathrm{La}$ and the segment to the NW (always further from the trench because the steps are all dextral) should have lower $\mathrm{Ba} / \mathrm{La}$. At the boundary between centr al and western Costa Rica there is no step in the volcanic front but there is a tear in the Cocos Plate allowing the western Costa Rica segment to have a greater depth to the seismic zone. However, that segment has higher $\mathrm{Ba} / \mathrm{La}$, not lower. The largest st ep along the volcanic front occurs at the boundary between western Costa Rica and eastern Nicaragua, but instead of a sharp drop in $\mathrm{Ba} / \mathrm{La}$ into Nicaragua, there is no obvious change. The step between eastern and western Nicaragua is at least $10 \mathrm{Km}$, but $\mathrm{Ba} / \mathrm{La}$ does not drop, instead it increases. The step between western Nicaragua and El Salvador is on the order of $10 \mathrm{Km}$ and here the $\mathrm{Ba} / \mathrm{La}$ ratio sharply decreases. The boundary between El Salvador and Guatemala is a change in strike rather than a rightward s tep and a large increase occurs not a decrease. The two assumptions, that the Wadati-Benioff zone has a simple geometry and that depth to the seismic zone controls $\mathrm{Ba} / \mathrm{La}$, fail to explain the $\mathrm{Ba} / \mathrm{La}$ offsets and lack of offsets seen in Central America.

\section{CONCLUSIONS}

Central American volcanoes provide a rich physical and 
1. The first-order geochemistry of the mafic volcanic front is known, but few volcanic centers have been comprehensively studied.

2. Silicic volcanic centers have been or are being studied in Guatemala, El Salvador and Costa Rica, but, in Nicaragua, there are several small silicic calderas that have not been investigated.

3. The secondary front of isolated composite volcanoes, located 20 to $75 \mathrm{Km}$ behind the main front, should be integrated into regional volcanological and geochemical investigations.

4. Important aspects of the magma genesis of the high -Ti lavas in Nejapa and Granada, Nicaragua remain unresolved.

5. Are the short, cross arc gradients in the paired volcanoes of northern Central America the result of mixing between low -Ti basalts and back-arc, high-Ti basalts?

6. The existence of cross-arc geochemical variation within most volcanic front centers in Guatemala contrasts with the lack such variation in Nicaragua. This discrepancy emphasizes how little is known abo ut magma flow paths and the loci of melting.

7. The transition between EMORB mantle beneath Nicaragua and OIB mantle beneath central Costa Rica occurs in easternmost Nicaragua and western Costa Rica. Is the transition, sharp, gradual or intermingled?

8. Do the regional variations in slab signal mean there are regional variations in slab flux or constant flux with regional variations in degree of melting caused by variable focusing of the flux? If the volcanic output rate were constant along the arc, the for mer would be the case, but currently available volume data and age estimates favor the latter because there is low magma output in Nicaragua, where the slab signal is at the maximum.

9. Some of the detailed systematics in isotopic and trace element ratios ar e difficult to explain unless the sources involved are repeatedly tapped in just the right proportions.
12. The breaks between the volcanic lines that comprise the Central American volcanic front corresponds with discontinuities in the regional slab signal, including three changes in the gradient and three abrupt offsets in the slab signal.

Acknowledgements. R.E. Stoiber and his numerous students and colleagues did much of the work on Central America described here. The chain of inspiration started by Dick is long and rich and we will miss his challenging insights. This work was partially supported by National Science F oundation Grants EAR 9628251, EAR 9905167, OCE-9521716 and EAR 9406624. We thank J. Whitlock for her careful measurements of the volumes of volcanic centers. We thank Louise Bolge for use of new data from Arenal volcano. R. Stern, J. Eiler and G. Alvara do provided useful criticisms that greatly improved this work. R. Harwood and B. Cameron made exceptional contributions to the field work.

\section{REFERENCES}

Abratis, M. and G. Wörner, Ridge collision, slab -window formation, and the flux of Pacific asthenosphere into the Caribbean realm. Geology, 29, 127-130, 2001.

Alvarado, G. E. and M. J. Carr, The Platanar-Aguas Zarcas volcanic centers, Costa Rica: Spatial-temporal association of Quaternary calc-alkaline and alkaline volcanism. Bull. Volcanol., 55, 443-453, 1993.

Aubouin, J., J. Azema, J-Ch. Carfantan, A. Demant, C. Rangin, M. Tardy and J. Tournon, The Middle America trench in the geological framework of Central America, in Initial Rep. Deep Sea Drill. Proj. 67, 747-755, 1982.

Burkart, B. and S. Self, Extension and rotation of crustal blocks in northern Central America and effect on the volcanic arc, Geology, 13, 22-26, 1985.

Cameron, B. I., J. A. Walker, M. J. Carr, L.C. Patino and O. Matías, Contrasting melt generation processes at front stratovolcanoes in sou theastern Guatemala, J. Volcanol. Geotherm. Res., in press.

Carr, M. J., Symmetrical and segmented variation of physical and geochemical characteristics of the Central American volcanic front, J. Volcanol. Geotherm. Res., 20, 231-252, 1984.

Carr, M. J., and W. I. Rose Jr., CENTAM-a data base of analyses of Central American volcanic rocks, J. Volcanol. Geotherm. Res. 33, 239-240, 1987.

Carr, M. J., and R. E. Stoiber, Geologic setting of some destructive earthquakes in Central America. Geol. Soc. Amer. Bull., 89, 151-156, 1977.

Carr, M. J., and R. E. Stoiber, Volcanism, in The Geology of North

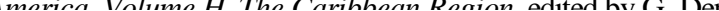


for modifications of subarc mantle by slab -derived flu ids, Chemical Geology, 160, 255-280, 1999.

de Boer, J. Z., M. J. Defant, R.H. Stewart and H. Bellon, Evidence for active subduction below western Panama, Geology, 19, 649-652, 1991.

de Bremond D'ars, J., C. Jaupart and R.S.J. Sparks, Distribution of volcanoes in active margins, J. Geophys. Res., 100, 2042120432, 1995.

Defant, M. J., T. E. Jackson, M. S. Drummond, J. Z. de Boer, M D. Feigenson, R. C. Maury, and R. H. Stewart, The geochemistry of young volcanism throughout western Panama and southeastern Costa Rica, an overview, J. Geol. Soc. Lond. 149, 569-579, 1992.

Dollfus, A., and E. Montserrat, Voyage geologique dans les republiques de Guatemala et de Salvador: France, Mission Scientifique au Mexique at dans l'Amerique Centrale, Geologie, 9, 539 pp, Imprimerie imperiale, Paris, 1868.

Drummond, M. S., M. Bordelon, J. Z.de Boer, M. J. Defant, H. Bellon and M.D. Feigenson, Igneous petrogenesis and tectonic setting of plutonic and volcanic rocks of the Cordillera de Talamanca, Costa Rica-Panama, Central American arc: American Journal of Science, 295, 875-919, 1995.

Ehrenborg, J., A new stratigraphy for the Tertiary volcanic rocks of the Nicaraguan highland, Geol. Soc. America. Bull., 108, 830-842, 1996.

Fairbrothers, G. E., M. J. Carr, and D. G Mayfield, Temporal magmatic variation at Boquerón Volcano, El Salvador, Contrib. Mineral. Petrol., 67, 1-9, 1978.

Feigenson, M. D. and M. J. Carr, The source of Central American lavas: inferences from geochemical inverse modeling, Contrib. Mineral. Petrol., 113, 226-235, 1993.

Feigenson, M. D. and M. J. Carr, Positively correlated Nd and Sr isotope ratios of lavas from the Central American volcanic front, Geology, 14, 79-82, 1986.

Feigenson, M. D., M. J. Carr, L. C. Patino, S. Maharaj and S. Juliano, Isotopic identifica tion of distinct mantle domains beneath Central America, Geol. Society of America, Abstracts with Programs, 28, 380, 1996.

Halsor, S. P. and W. I. Rose Jr., Common characteristics of active paired volcanoes in northern Central America, J. Geophys. Res., 93, 4467-4476, 1988.

Harry, D. L. and N. L. Green, Slab dehydration and slab petrogenesis in subduction systems involving very young oceanic lithosphere, Chemical Geol., 160, 309-333, 1999.

Herrstrom, E. A., M. K. Reagan, and J. D. Morris, Variations in lava composition associated -with flow of asthenosphere beneath southern Central America, Geology 23, 617-620, 1995.

Johnston, S.T., and D. J. Thorkelson, Cocos -Nazca slab window beneath Central America, Earth Planet. Sci. Lett., 146, 465474, 1997

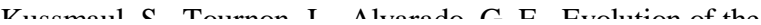

Malavassi, E., Magma sources and crustal processes at the southern terminous of the Central American volcanic front PhD. Thesis, 435pp., Univ. Calif. Santa Cruz, 1991.

McBirney, A. R., Volcanic evolution of Central America. Boletín Vulcanología, Heredia, Costa Rica. 14, 21-23, 1985.

Noll, P. D., H. E. Newsom, W. P. Leeman and J. G. Ryan, The role of hydrothermal fluids in the production of subduction zone magmas: Evidence from siderophile and chalcophile trace elements and boron. Geochim Cosmochim Acta, 60, 587-612, 1996.

Patino, L. C., M. J. Carr and M. D. Feigenson, Cross -arc geochemical variations in volcanic fields in Honduras, C. A. Progressive changes in source with distance from the volcanic front, Contrib. Mineral. Petrol., 129, 341-351, 1997.

Patino, L. C., M. J. Carr and M.D. Feigenson, Local and regional variations in Central American arc lavas controlled by variations in subducted sediment input, Contrib. Mineral. Petrol., 138, 265-283, 2000.

Plank, T. and C.H. Langmuir, An evaluation of the glob al variations in the major element chemistry of arc basalts, Earth Planet. Sci. Lett., 90, 349-370, 1988.

Plank, T. and C.H. Langmuir, Tracing trace elements from sediment input to volcanic output at subduction zones, Nature, 362,.739-743, 1993

Pullinger, C., Evolution of the Santa Ana volcanic complex, El Salvador. M.S. Thesis, $251 \mathrm{pp}$, Michigan Technological University, Houghton, MI, 1998.

Protti, M., F. Gundel, and K. McNally, Correlation between the age of the subducting Cocos plate and the geometry of the Wadati-Benioff zone under Nicaragua and Costa Rica, Geol. Soc. Am. Spec. Pap., 295, p. 309-326, 1995.

Reagan, M. K. and J. B. Gill, Coexisting calc -alkaline and high niobium basalts from Turrialba volcano, Costa Rica:

Implications for residual titanate $\mathrm{s}$ in arc magma sources, $J$. Geophys. Res., 94, 4619-4633, 1989.

Reagan, M. K. J. D. Morris, E. A. Herrstrom and M. T. Murrell, Uranium series and beryllium isotope evidence for an extended history of subduction modification of the mantle below Nicaragua, Geochim. Cosmochim. Acta 58, 4199-4212, 1994.

Roggensack, K., R. L. Hervig, S. B. McKnight, S. N. Williams, Explosive basaltic volcanism from Cerro Negro Volcano: Influence of volatiles on eruptive style, Science 277, 16391642, 1997.

Rose Jr., W. I., F. M. Conway, C. R. Pullinger, A. Deino and W C Mclntosh, A more precise age framework for late Quaternary silicic eruptions in northern Central America, Bull. Volcanol., 61, 106-120, 1999.

Sisson, $\mathrm{T}$ and G. D. Layne, $\mathrm{H}_{2} \mathrm{O}$ in basalt and basaltic andesite glass inclusions from four subduction-related volcanoes, Earth Planet Sci. Lett., 117, 619-635. 1993. 
Sussman, D., Apoyo Caldera, Nicaragua: A major Quaternary silicic eruptive center, J. Volcanol Geotherm. Res. 24, 249-282, 1985.

Tournon, J., Magmatismes du mesozoique à l' actuel en Amerique Centrale: L'exemple de Costa Rica, des ophiolites aux andesites, Ph.D. thesis, 335 pp., Mém. Sc. Terre, Univ. Curie, Paris, 84-49, 1984.

Ui, T., Recent volcanism in the Masaya -Granada area, Nicaragua, Bull. Volcanol. 36, 174-190, 1972.

van Wyk de Vries, B., Tectonics and magma evolution of Nicaraguan volcanic systems, Ph.D. Thesis, 328pp., Open University, Milton Keynes, UK, 1993.

von Huene, R., C. R. Ranero, W. Weinrebe and K. Hinz, Quaternary convergent margin tectonics of Costa Rica: Segmentation of the Cocos Plate, and Central American volcanism, Tectonics, 19, 314-334, 2000.

Walker, J. A., Petrogenesis of lavas from cinder cone fields behind the volcanic front of Central America, J. Geol., 87, 721739,1981

Walker, J. A., Volcanic rocks from the Nejapa and Granada cinder cone alignments, Nicaragua, J. Petrol., 25, 299-342, 1984.

Walker, J. A., M. J. Carr, M. D. Feigenson and R. I. Kalamarides, The petrogenetic significance of High -and Low-Ti basalts in Central Nicaragua, J. Petrol., 31, 1141-1164, 1990.

Walker, J. A., M. J. Carr, L. C. Patino, C. M. Johnson, M. D. Feigenson and R. L. Ward, Abrupt change in magma generation processes across the Central American arc in southeastern

Guatemala: flux-dominated melting near the base of the wedge to decompression melting near the top of the wedge, Contrib. Mineral. Petrol., 120, 378-390, 1995.

Walker, J. A, L. C. Patino, B. I. Cameron and M. J. Carr, Petrogenetic insights provided by compositional transects across the Central American arc: Southeastern Guatemala and Honduras, J. Geophys. Res., 105, 18,949-18,963, 2000.

Walker, J. A, L. C. Patino, M. J. Carr and M. D. Feigenson, Slab control over HFSE depletions in central Nicaragua, Earth Planet. Sci.Lett., 192, 533-543, 2001.

Walker, J. A., S. N. Williams, R. I. Kalamarides, and M. D. Feigenson, Shallow open -system evolution of basaltic magma beneath a subduction zone volcano: the Masaya caldera

complex, Nicaragua, J. Volcanol. Geotherm. Res., 56, 379-400, 1993.

Weyl, R., Geology of Central America, 372 p., Gebrüder Borntraeger, Berlin, 1980

White, R. A., and D. Harlow, Destructive upper -crustal earthquakes of Central America since 1900, Bull. Seismol. Soc. America, 83, 1115-1142, 1993.

Williams, S. N., The October 1902 plinian eruption of Santa María volcano, Guatemala, J. Volcanol. Geotherm. Res., 16 , 33-56, 1983a.

Williams, S. N., Plinian airfall deposits of basaltic composition, Geology, 11, 211-214, 1983b. 
FIGURE CAPTIONS 4.5 inch width

Figure 1. Volcanological and tectonic framework of Central America. AZ is Aguas Zarcas. Tal. is the Talamanca range in southern Costa Rica.

Figure 2. Locations of volcanic centers and BVF fields. E.S. is El Salvador, C.R. is Costa Rica. The abbreviations are: in El Sa lvador, Iz for Izalco, C for Conchaguita, M for

Meanguera; in Nicaragua, R for Rota, $\mathrm{M}$ for Maderas; in Costa Rica, $\mathrm{T}$ for Turrialba. The stippled areas show approximate extents of the BVF volcanic fields with high -Ti character.

Figure 3. Geochemistry of DSDP 495 section. Stippled diamonds are EMORB an NMORB from Sun and McDonough [1989]. Filled triangles are carbonate sediments. Open triangles are hemipelagic sediments.

Figure 4. Crustal and mantle variations along the strike of the Central American volc anic front.

Figure 5. Regional variation in crustal thickness, $\mathrm{Na}{ }_{52}, \mathrm{U} / \mathrm{Th}$ and $\mathrm{La} / \mathrm{Yb} . \mathrm{Na}_{52}$ is $\mathrm{Na}_{2} \mathrm{O}$ content of lavas with $\mathrm{SiO}_{2}$ contents between 48 and 55 , corrected to $52 \% \mathrm{SiO}_{2}$ via $\mathrm{Na}_{52}=$ $\mathrm{Na}_{2} \mathrm{O}-\left(\mathrm{SiO}_{2}-52\right) * 0.14$.

Figure 6. Intravolcano variation at Arenal and Telica volcanoes. Balloons enclose low -Ti lavas at Arenal and Telica volcanoes, which define arrays, called the local variation by Patino et al. (2000). The open symbols are low -Ti lavas from eastern Nicaragua, where no local variation is present. The eastern Nicaragua array extends from near the mantle (EM) to progressively closer to the sediment array that is parallel to the Telica array but well outside the diagram. The arrows point toward the locations of the ends of the sediment array.

Figure 7. Segmentation of the volcanic front. Panel 7a shows the volumes of the 39 Central America volcanic centers. Panel $7 \mathrm{~b}$ shows the plate boundaries, the volcanic front (circles), boundaries of volcanic segments (stippled bars) and structural boundaries in the Cocos Plate [von Huene et al., 2000] and inclined seismic zone; bend, QSC, and end [Protti et al., 1994]. 


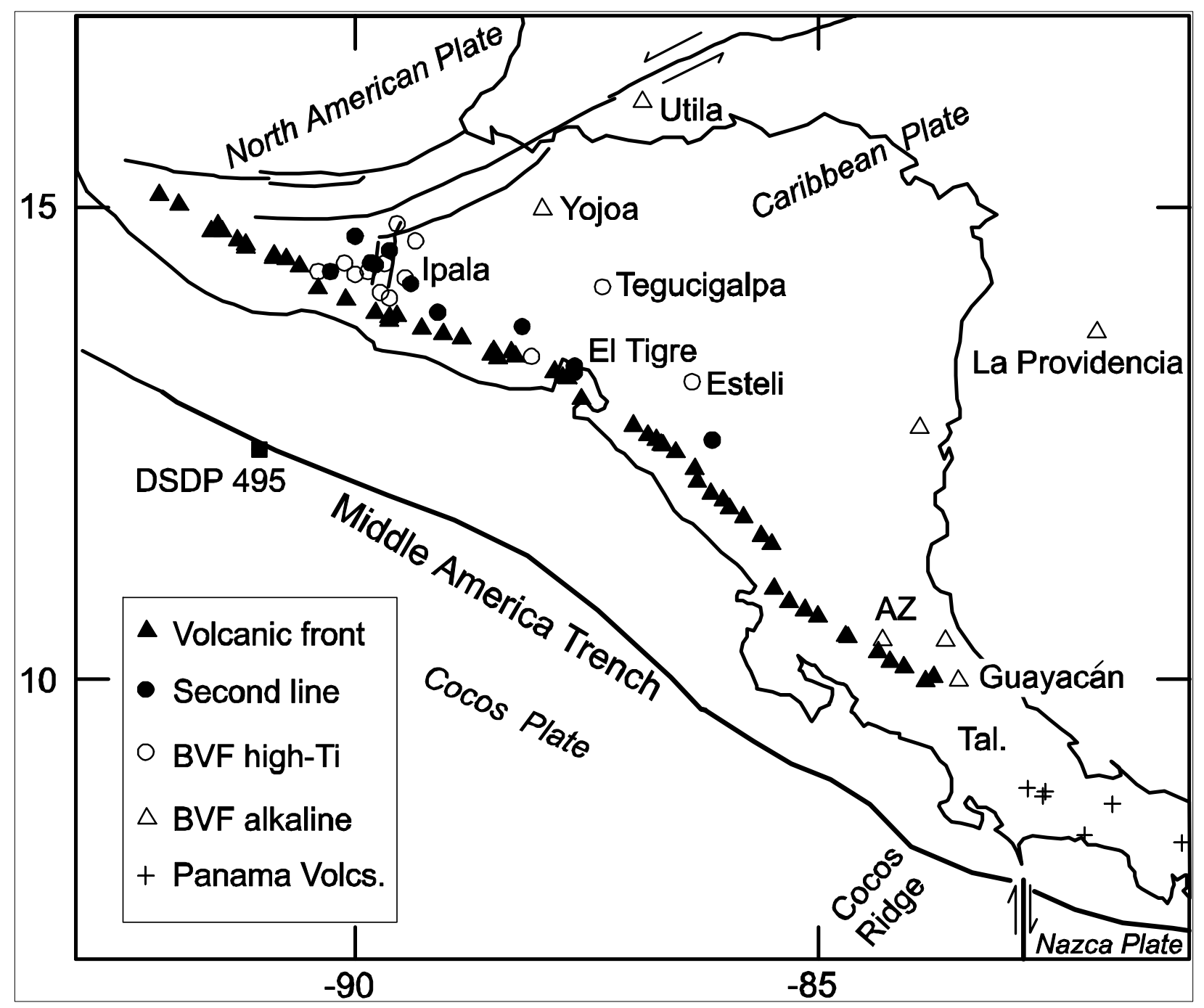

Figure 1. Volcanological and tectonic framework of Central America. AZ is Aguas Zarcas. Tal. is the Talamanca range in southern Costa $\mathrm{R}$ ica. 


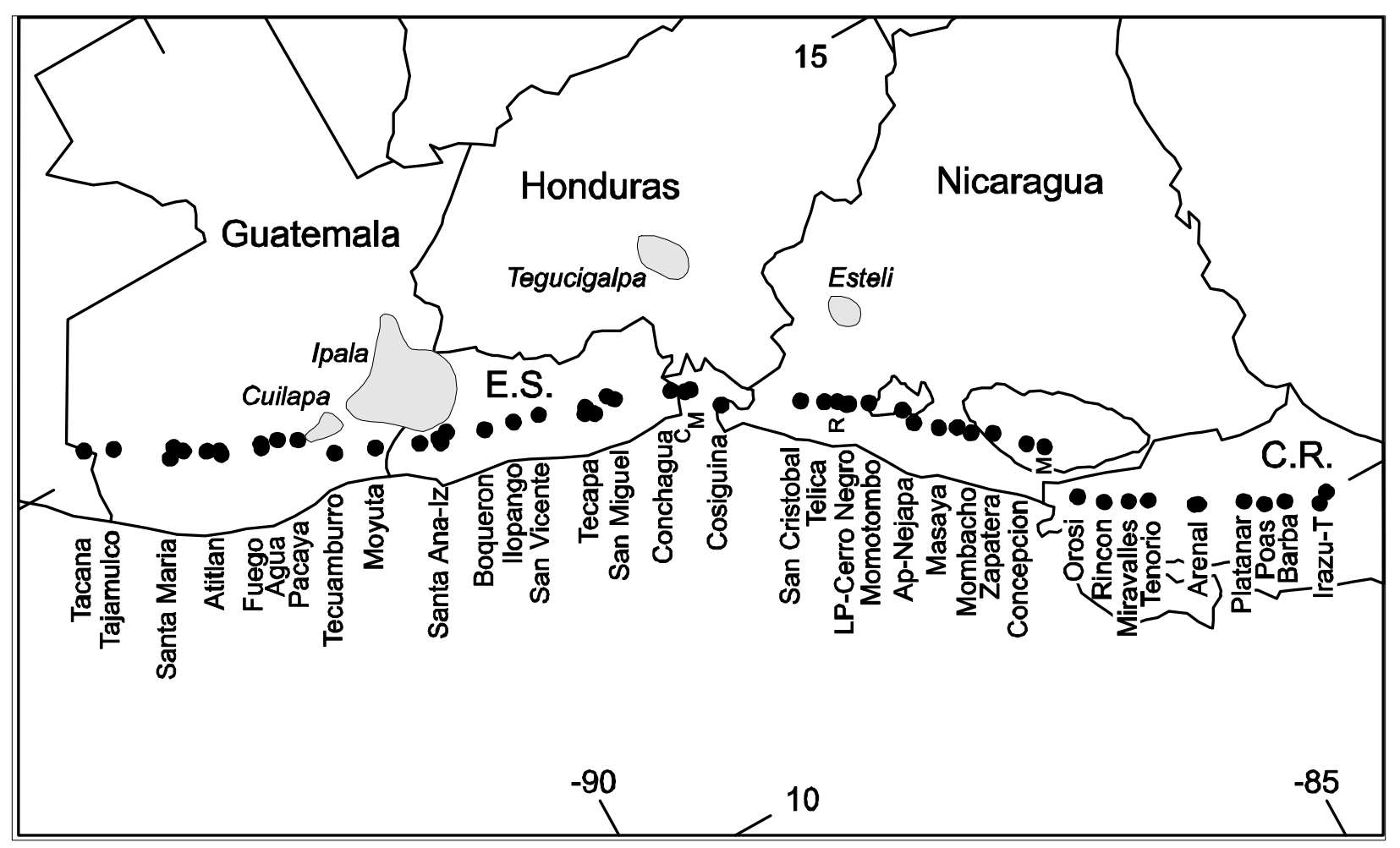

Figure 2. Locations of volcanic centers and BVF fields. E.S. is El Salvador, C.R. is Costa Rica. The abbreviations are: in El Salvador, Iz for Izalco, $\mathrm{C}$ for Conchaguita, M for

Meanguera; in Nicaragua, R for Rota, M for Maderas; in Costa Rica, T for Turrialba. The stippled areas show approximate extents of the BVF volcanic fields with high -Ti character. 


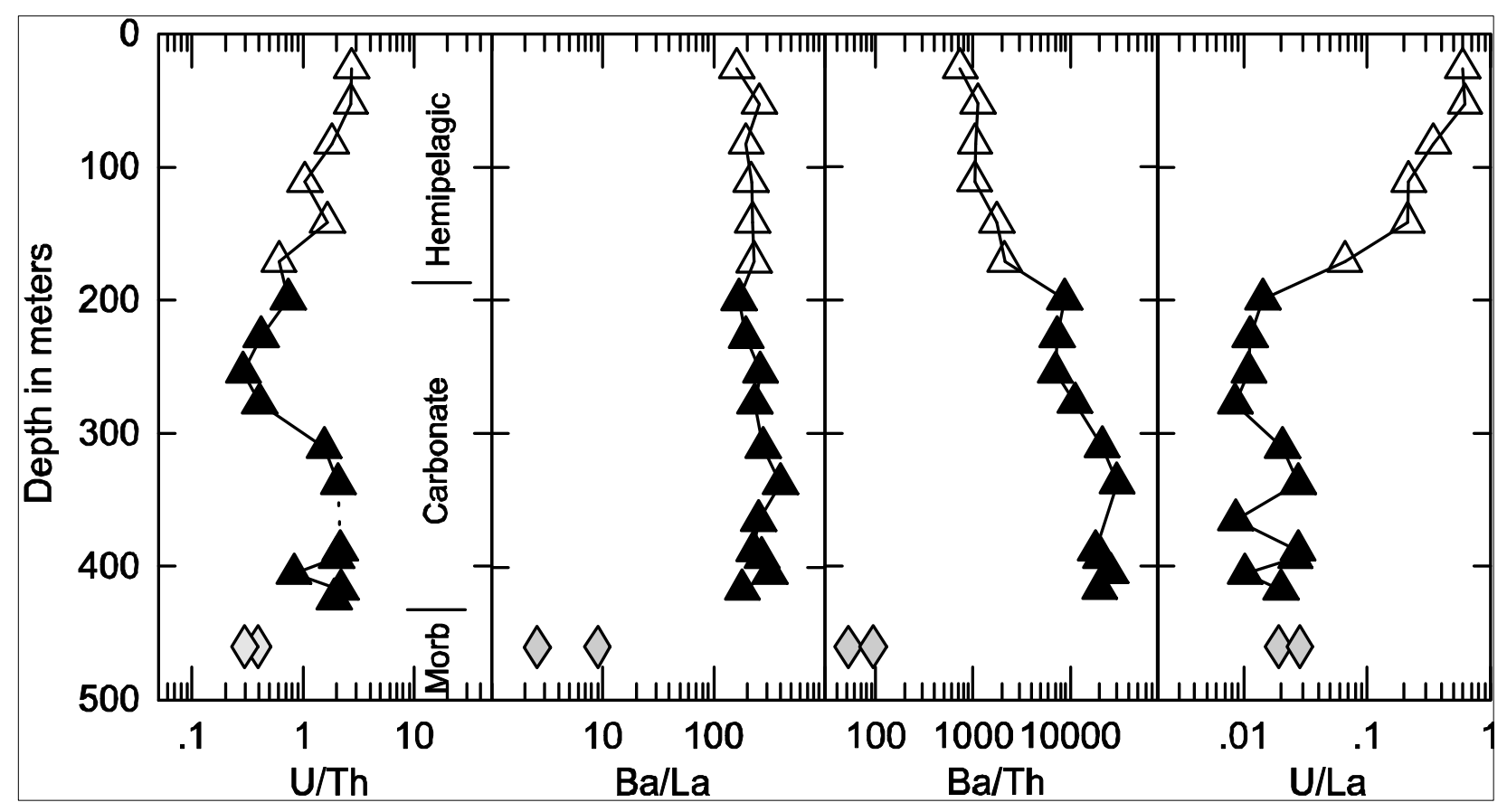

Figure 3. Geochemistry of DSDP 495 section. Stippled diamonds are EMORB an

NMORB from Sun and McDonough [1989]. Filled triangles are car bonate sediments. Open triangles are hemipelagic sediments. 


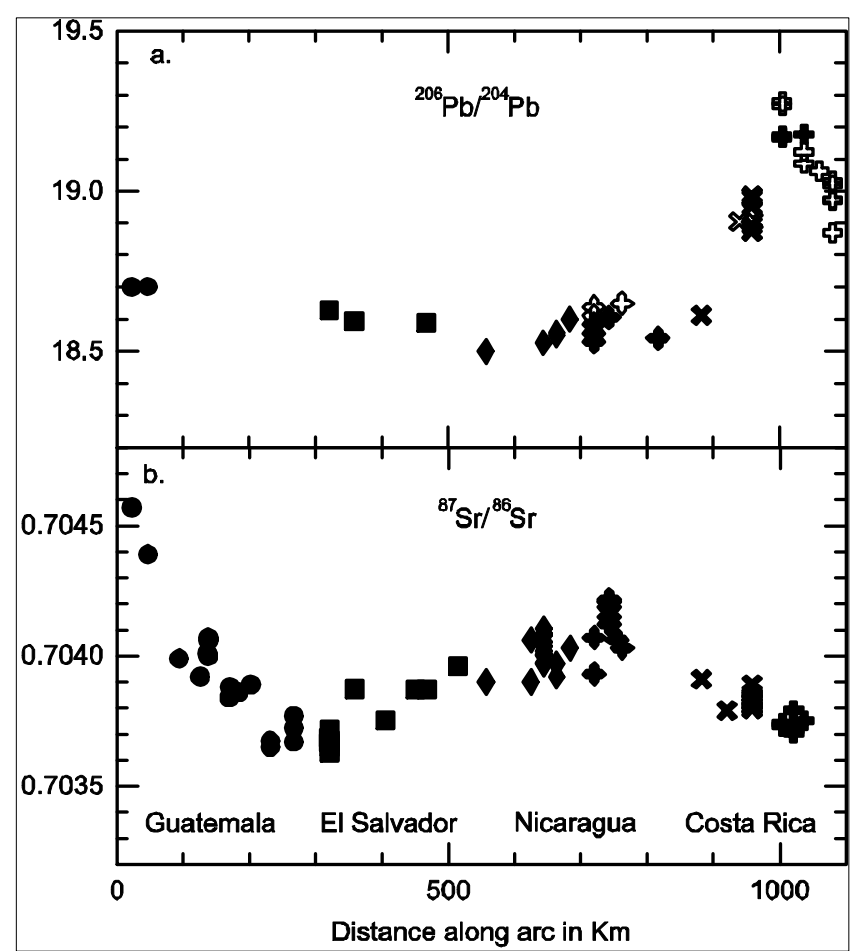

Figure 4. Crustal and mantle variations along the strike of the Central American volcanic front. 


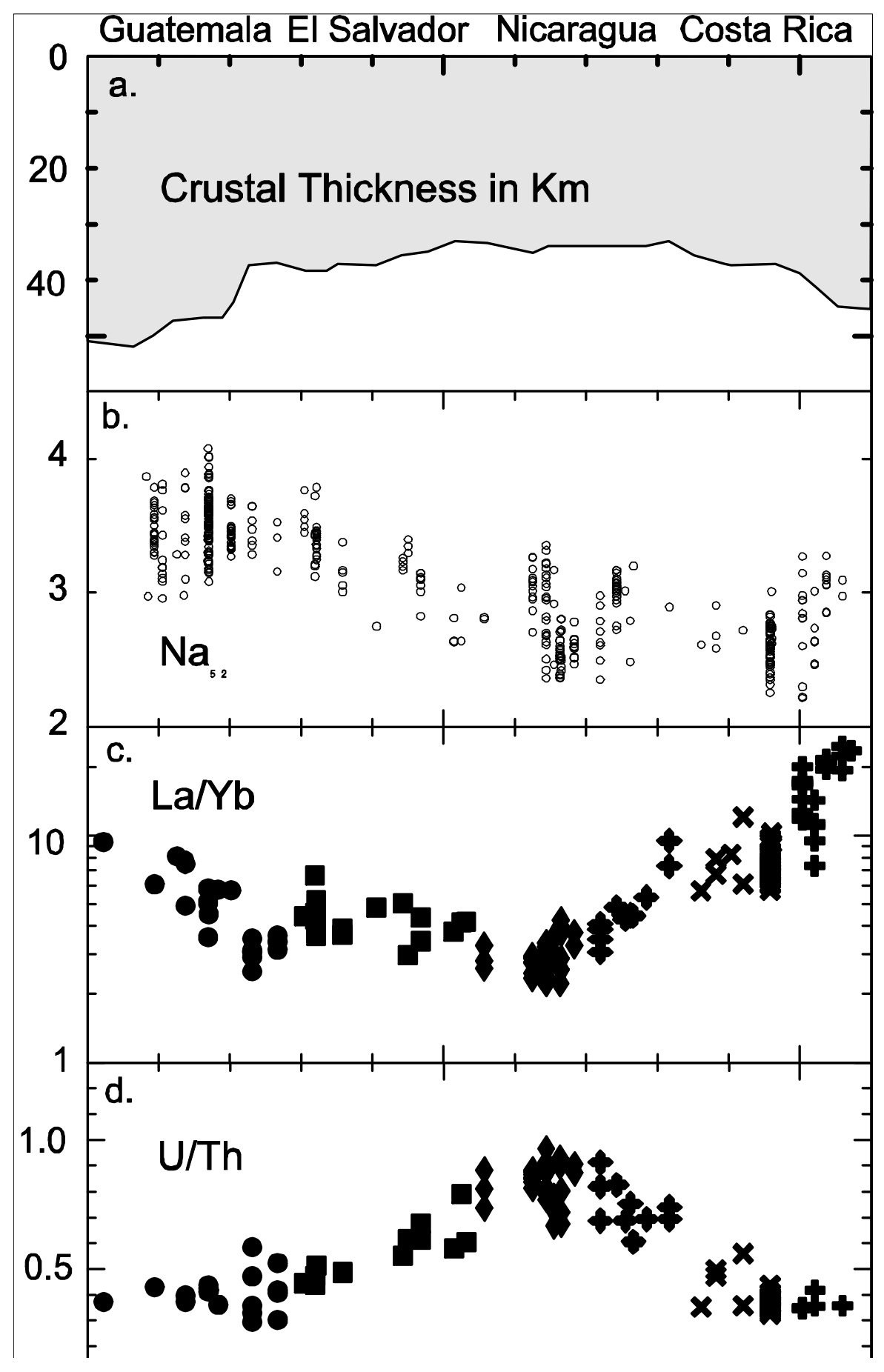




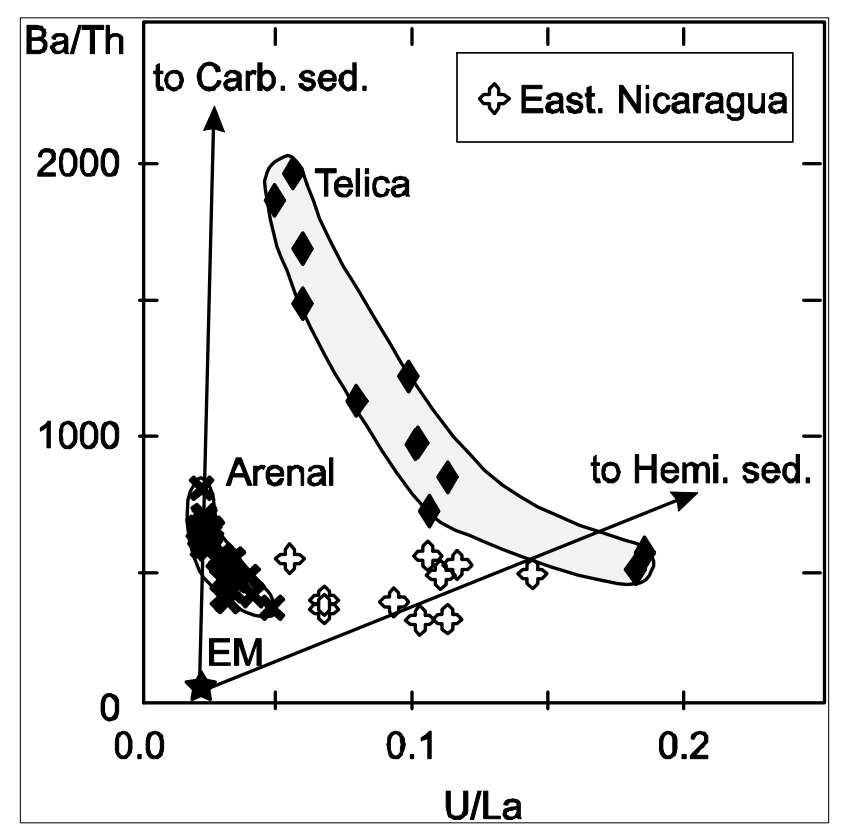

Figure 6. Intravolcano variation at Arenal and Telica volcanoes. Balloons enclose low -Ti lavas at Arenal and Telica volcanoes, which d efine arrays, called the local variation by

Patino et al. (2000). The open symbols are low -Ti lavas from eastern Nicaragua, where no local variation is present. The eastern Nicaragua array extends from near the mantle (EM)

to progressively closer to the s ediment array that is parallel to the Telica array but well outside the diagram. The arrows point toward the locations of the ends of the sediment array. 


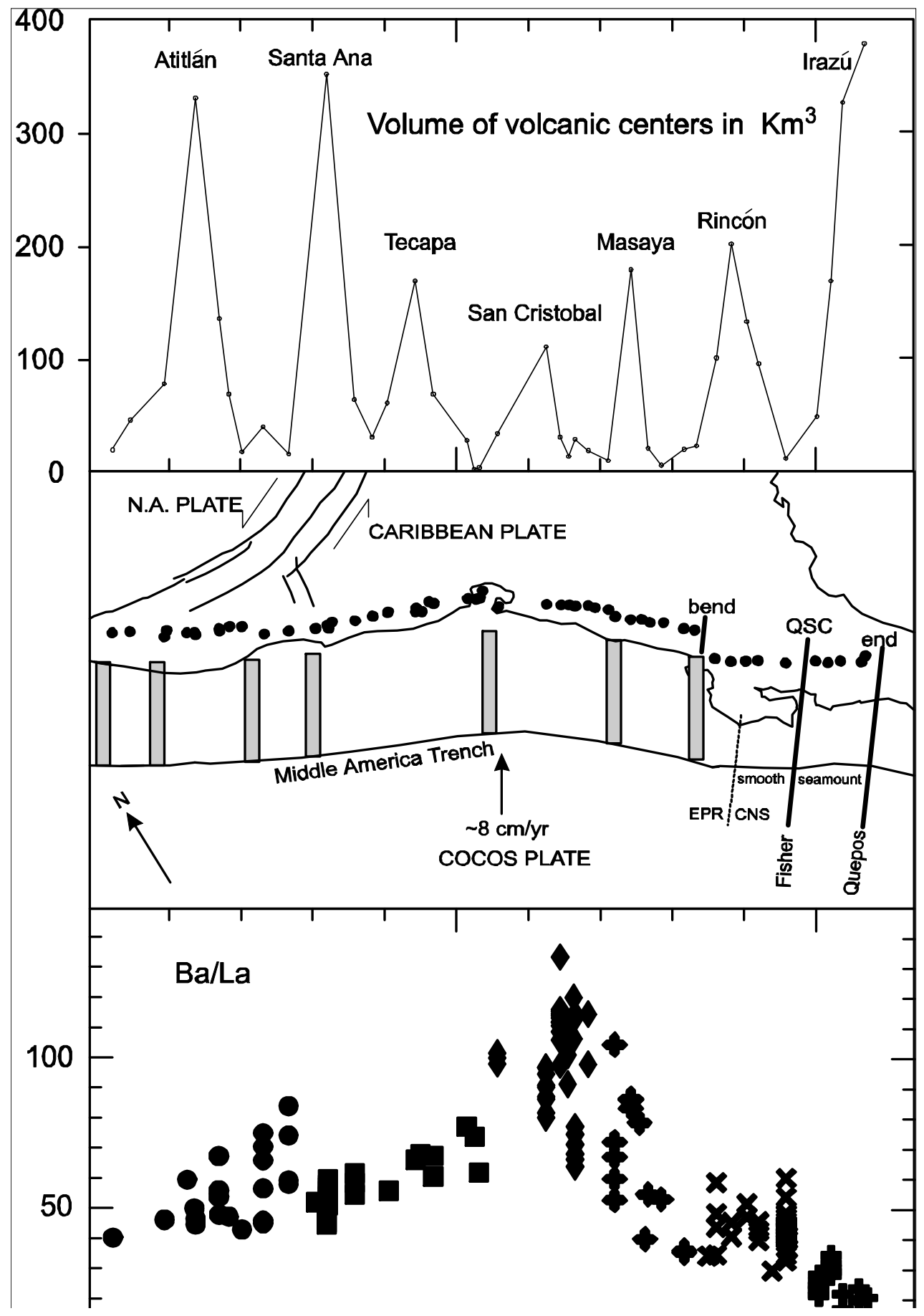

